\title{
Pripadnost Terezije Avilske fundamentalnoj teologiji
}

Edvard Punda*

\begin{abstract}
Sažetak
Ove se godine (2015) slavi 500. godišnjica rođenja svete Terezije Avilske (1515.1582.). Budući da je Terezija prva žena kojoj je Crkva udijelila naslov naučitelja, potvrđujući, uz njezinu svetost, i eminentan nauk sadržan u njezinim djelima, $i$ sama je teologija na neki način na nju upućena. Stoga je ova velika obljetnica izvrsna prigoda da se avilska svetica, kroz temu ovoga rada, predstavi i hrvatskoj teološkoj sceni, u kojoj je Terezija tek neznatno prisutna. Nakana nam je teološku relevantnost Terezijine misli, predstaviti na način da se samoj Tereziji »otvori« jedno mjesto u teološkome svijetu, konkretno u fundamentalnoj teologiji. U prvome dijelu tumači se važnost iskustva kao spoznajno-afektivnoga procesa iz kojega nastaju Terezijina djela. Unutar toga procesa krije se istinska teološka metoda koju autor predlaže fundamentalnoj teologiji kao onoj teološkoj disciplini koja je prva odgovorna za promišljanje o metodi u teologiji. Drugi dio pruža sustavni presjek teološkoga sadržaja življenoga i mišljenoga unutar mističnog iskustva. Riječ je o sretnome spoju između fides quae creditur $i$ fides qua creditur, pri čemu su objavljene istine središte kršćanske egzistencije, a da se time ne svode na pojedina iskustva. Na kraju se, ukratko, uvijek s obzirom na Terezijine misli, ukazuje na važnost molitve za teološku egzistenciju, ali i kako teološki rad može postati molitvom.
\end{abstract}

Ključne riječi: Terezija Avilska, fundamentalna teologija, iskustvo, teološka metoda, molitva

\section{Uvod}

Iako postoje vrijedne biografije i iscrpne povijesne studije o Tereziji, upravo su njena djela glavni izvor za upoznavanje Svetice. ${ }^{1}$ Naime, dovoljan je samo leti-

* Dr. sc. Edvard Punda, Katolički bogoslovni fakultet Sveučilišta u Splitu. Adresa: Zrinjsko-Frankopanska 19, 21000 Split. E-pošta: donedvard@gmail.com

1 Terezijina djela navodimo skraćenicama: $\check{Z}=$ Moj život; $\mathrm{Z}=$ Zamak Duše (npr. Z 1, 2, 3 = Zamak duše, 1. Odaje, 2. Poglavlje, 3. Odlomak); VDB = Vapaji duše Bogu; MLJB = Misli o ljubavi Božjoj; $\mathrm{PS}=$ Put $k$ savršenosti $; \mathrm{O}=$ Osnutci, $\mathrm{I}=$ Duhovni izvještaji $; \mathrm{Pj}=$ Pjesme . 
mičan pogled na Terezijina djela, da bi se uvidjelo da se radi o autorici koja piše o sebi, o vlastitim duhovnim iskustvima. Ona su sadržaj njezinih djela. Svi drugi podatci, biografski i ostali povijesni, uglavnom su u službi opisa nutarnjih događanja.

Teološki studiji iskustava avilske svetice najčešće slijede dva osnovna pristupa. Prvi - koji slijedi većina autora - prati biografsko-kronološki razvoj, pri čemu se kao »događaj razdjelnica « navodi takozvano Terezijino »treće ili konačno « obraćenje, iz 1554. godine ${ }^{2}$, nakon kojega započinju iskustva koja će Terezija opisivati u svojim djelima. Posebna je vrijednost ovoga pristupa, kako će se vidjeti, što prati nutarnju dinamiku iskustva.

Drugi polaze »od kraja«, od punine njezinih iskustava, i promatraju Tereziju iz perspektive sedmih odaja Zamka duše, u kojima opisuje svoje shvaćanje punine kršćanskoga življenja. One su sastavljene od četiriju poglavlja koja strukturalno definiraju Terezijino iskustvo kroz četiri velike dogmatske teme: otajstvo PresvetogaTrojstva, otajstvo Krista, otajstvo čovjeka u Kristu i otajstvo Crkve. Na ovaj se način izravnije pristupa sadržaju samih iskustava.

U ovom će se radu pokušati objediniti ta dva pristupa, što će pomoći da se vidi $\mathrm{u}$ čemu Terezijina iskustva mogu doprinijeti fundamentalnoj teologiji s obzirom na metodu, a u čemu s obzirom na sadržaj njezinih promišljanja. U prvom dijelu predstavit će se dinamika onih Terezijinih iskustava iz kojih se rađa sav njezin nauk. To »rađanje«, od početka mističnih iskustava do njihova razumijevanja i sposobnosti verbaliziranja, otkriva pravu teološku metodu, a posljedično i mnoge elemente koji mogu biti korisni za promišljanje o egzistenciji teologa. ${ }^{3}$

U drugome ce se dijelu, u najosnovnijim crtama, predstaviti (dogmatski) sadržaj Terezijinih iskustava, objavljen i življen u molitvi. Molitva je, naime, ambijent onih iskustava koja su izvor teološke spoznaje avilske svetice. Terezijini spisi svjedoče kako sadržaj objave može (i treba) postati sadržaj ljudske egzistencije, te kako je svaka pojedina egzistencija jedna mikro-povijest spasenja, sa svim njezinim elementima.

Po sebi je razumljivo da naslov Pripadnost Terezije Avilske fundamentalnoj teologiji ne želi sav teološki materijal koji je iznjedrilo Terezijino iskustvo »strpati u koš« ove teološke discipline, niti znači da se kod Terezije nužno nalaze svi elementi onoga čime se danas bavi fundamentalna teologija. Ovdje se također ne otkrivaju nova polja prema kojima bi se mogla usmjeravati ova teološka disciplina. Kod Terezije uočava se ona »teologija« koja se rađa iz jedinstva življenoga i mišljenoga. Koncentriranost na sadržaj iskustva i promišljanje o onome što se događa u onome tko vjeruje, ovdje su neodvojivi. Fides quae i fides qua prožimaju se.

2 E. de la Madre de Dios - O. Steggink, Tiempo y vida de Santa Teresa, Madrid, 1996, str. 142-148. Autori donosi različita mišljenja vezana uz datum razdjelnicu, navodeći ipak kao najvjerojatniju godinu 1554. Isto, str. 147-148.

3 Fundamentalna teologija, kao ona grana teologije koja se bavi »istraživanjem objave i njezine vjerodostojnosti, zajedno sa činom vjere koji joj odgovara « (Fides et Ratio, 67) prva je pozvana promišljati o teološkoj egzistenciji kao posebnoj vrsti vjerničke egzistencije. To uključuje i zanimanje za teološki rad kao konstitutivni element biti-teolog. Usp. Z. Alszeghy - M. Flick, Come si fa la teologia, Alba, 1974, str. 14-24; 137-169. 
Ukratko: Tereziji će se pokušati dati onaj smještaj u fundamentalnu teologiju od kojega i sama fundamentalna teologija - u svome poslanju obrazlaganja nade i vjere (usp. 1 Pt 3, 15) - može imati koristi.

\section{Dinamizam iskustva i teološka egzistencija}

Iskustvo (iskusiti, kušati) vrlo je važna riječ unutar Terezijina pisanog opusa. ${ }^{4}$ Ona zauzima središnje mjesto s obzirom na spoznaju i ona je za nju kriterij istinitosti vlastitih iskaza: »Neću reći ništa što ne bih bila dobro iskusila « $(\check{Z} 18,8){ }^{5}$ Ono u Terezijinu slučaju, kako će se dalje vidjeti, ima i posebnu specifikaciju: iskustvo koje je izvor Terezijine spoznaje mistično je iskustvo. Ovdje nije moguće ulaziti u svu (teološku) problematiku vezanu uz stvarnost i pojam iskustva ${ }^{6}$, niti određivanje teološkoga statusa mističnog iskustva, njegove relevantnosti za teologiju i njegova značenja za kršćansku egzistenciju. ${ }^{7}$ Recimo samo da se ne radi o iskustvu u kojem bi se dale neke druge istine vjere u odnosu na ono što se naziva redovitim/svakodnevnim iskustvom vjere, ili iskustvo u kojem bi te istine bile nadiđene. Naime, »istinska teologija milosti, vjere [...], ako želi biti istinska teologija milosti, ne može umetnuti između vjere i iskustva milosti, s jedne, i slave, s druge strane, neko međustanje koje bi se teološki bitno razlikovalo od jedne i od druge ${ }^{.}$.

\subsection{Iskustvo: motiv i sadržaj Terezijina nauka}

Sva Terezijina djela nastala su u zadnjoj trećini njezina života, koji će ona sama definirati kao novi život. ${ }^{9}$ Piše nakon duga razdoblja mističnih iskustava o čemu se, s obzirom na datum, terezijanisti uglavnom slažu. Početak mističnih iskustava — za koje Terezija kaže da »niti ga se poželjelo, niti pak bijaše do mene doprlo saznanje da to može biti« (Ž 27, 7) — označen je jakom sigurnošću Božje prisutnosti, a opisuje ga ovako: »Doživljavala sam nekoliko puta [...] da bi me odjednom obuzeo osjećaj Božje nazočnosti, te nikako nisam mogla posumnjati da

4 Prema Konkordanciji Terezijinih spisa, pojam »iskustvo« u raznim se inačicama (imenica, glagol i pridjev) pojavljuje oko 210 puta. J. L. Astigarraga - A. Borrell, (ur.), Concordancias de los escritos de Santa Teresa de Jesús, I, Rim, 2000, str. 1118-1121.

5 »Iz iskustva znam da je istina to što kažem« $(\check{Z}$ 27, 11).

6 Iz mnoštva bibliografije navodimo samo klasik svakog teološkog pristupa problematici iskustva J. Mouroux, L'esperienzacristiana. Introduzioneaunateologia, Brescia, 1956. Vrijedan pokušaj cjelovitoga pristupa toj višeznačnoj stvarnosti i prema nekima »najnerazjašnjenijem pojmu « (Gadamer), na hrvatskom jeziku, može se vidjeti u Zborniku radova teološkog simpozija održanog u Splitu 22. listopada 1999: N. A. Ančić - N. Bižaca (prir.), Iskustvo vjere danas, Split, 2000.

7 Jedan takav pokušaj može se vidjeti u sintetičkom radu G. Strzelczyk, L'esperienza mistica come locus theologicus. Status quaestionis, Lugano, 2005.

8 K. Rahner, Per una teologia della mistica, u: Isti, Visioni e profezie, Milano, 1995, str. 137. Drugim riječima, »s teološke točke gledišta, ne postoji na ovoj zemlji neko iskustvo Božjeg Duha koje bi bilo veće od vjere«. Isto, 138.

9 »To je druga, nova knjiga, odavde dalje; hoću reći drugi, novi život. Onaj dovde bijaše moj, a onaj kojim sam živjela otkad sam počela iznositi ove stvari o molitvi jest Bog koji je u meni« $(\check{Z} 23,1)$. 
je bio u meni ili ja sva uronjena u njega. To nije bila vrsta viđenja; mislim da to nazivaju mističnom teologijom « $(\check{Z} 10,1)$.

Prije samoga sadržaja iskustava zanima nas dinamizam koji im pripada. Svako iskustvo ovisi o kontekstu. Kontekst ga određuje. Mistično iskustvo, za svetu Tereziju, događa se na kraju jednog dugotrajnoga mučnog procesa, koji ona definira kao borba sa sjenom smrti, iz koje nikako nije mogla izići ma koliko god se trudila $(\check{Z}$ 12, 8). Mistično iskustvo događa se unutar te drame, stvarajući za nju nov početak, nov pogled na Boga, na svijet i na sebe samu.

U prvome redu, Terezija se pred novim iskustvima nalazi potpuno zbunjena. Ne može ih razumjeti. Refleksija ne uspijeva ići u korak s događajem koji iznenađuje i obuzima. Traži pomoć od svojih ispovjednika i duhovnih savjetnika, no umjesto rješenja, Terezija se susreće s novim problemom. Oni od nje traže da iskustva pretoči u pisanu formu. No kako iskazati ono što ni sama ne razumije? Nemoć/ nesposobnost ekspresije trajat će 4-5 godina, a završit će neočekivano, upravo onako kako su i započela mistična iskustva: »I, a da to nisam htjela niti tražila [...], Bog mi je to u jednom trenutku dao da shvatim i da znadem iskazati« $(\check{Z} 12,6)$.

Sama iskustva koja opisuje tjeraju je — bilo kao traženje drugih, bilo kao vlastito duhovno nagnuće - na pisanje. Stoga se može reći da su mistična iskustva istodobno i sadržaj i motiv Terezijinih djela. S epistemološke točke gledišta, ona su objekt naracije i izvor spoznaje.

Dinamizam od doživjeti, biti obuzeta do shvatiti i znati iskazati, sama je Terezija sažela u rečenicu iz koje se može dobiti njezina »teološka metoda«: »Jedna je milost da Gospodin daje milost, a druga je shvatiti kakva je milost i kakvo milosrđe. Treća je pak znati iskazati i objasniti kakva je« $(\check{Z} 17,5)$.

$\mathrm{S}$ obzirom na teološku metodu riječ je o affectus, intellectus i confessiofidei. Njena teologija, sadržaj njezinih djela, rađa se iz ovoga dinamizma. ${ }^{10}$ Ta metoda ne proturječi, a još manje isključuje dvojako metodološko načelo teologije kao znanosti: auditus fidei i intellectus fidei. Zapravo, čitav dinamizam Terezijina iskustva jest razumijevanje Božje riječi, koja je, u konačnici, kriterij autentičnosti svakoga iskustva: »Prema onome što vidim i znam iz iskustva, može se vjerovati da je od Boga ako je u skladu sa Svetim pismom « $(\check{Z} 25,12) .{ }^{11} \mathrm{Za}$ nju je cjelokupnost iskustva jedna dinamična intelligentia Verbi ${ }^{12}$, gdje se djelotvornost riječi pretače u poticaj na ljubav: »Njegove su riječi djela. O Bože mili, kako li jača vjera i uvećava se ljubav! «(Ž 25,18$)$. A to je i konačni smisao svake teologije. ${ }^{13}$

10 O tome: E. Punda, La fede in Teresa d'Avila, Rim, 2011, str. 63-81, posebno 79-81.

11 I više: »vjerujem da je objava bila istinska, ukoliko nije u protivnosti s onim što se nalazi u Svetom pismu ili pak protiv zakona Crkve koje smo obvezni poštivati« (Ž 32, 17). Doista, teologija se bavi onom božanskom istinom »koja nam je izložena u Svetom pismu shvaćenom u skladu s naučavanjem Crkve (Fides et Ratio, 66). Navedeni tekst je Sv. Tome, Summa Theologiae II-II, 5, 5 ad 2.

12 Terezija ne upada u subjektivizam. Riječ Božja je uvijek veća od iskustva i razumijevanja koje imamo s obzirom na nju: »Jedna jedina riječ Švelikoga Boga i GospodinaĆ u sebi sadržava tisuće tajni, pa stoga ne možemo razumjeti njihova počela (MLJB 1, 2).

13 »Ljubav ne goni samo vjeru na veću spoznaju, nego ne dopušta isto tako da se vjera ukine u spoznaji . I. Raguž, Neki vidovi teologije vjere Tome Akvinskoga, u: Diacovensia 21 (2013.) 2, str. 302, bilješka 64 . 


\subsection{Neke odrednice dinamike Terezijina iskustva koje mogu koristiti fundamentalnoj teologiji}

Zanimaju nas, dakle, samo neke odrednice imanentne iskustvenom procesu affectus-intellectus-confessio, a u kojima pronalazimo elemente relevantne za organiziranje fundamentalne teologije.

\section{- Affectus - čuđenje/divljenje kao uvjet teologije}

»Svako istinsko iskustvo započinje s iznenađenjem i čuđenjem «. ${ }^{14}$ Subjekt biva zahvaćen događajem koji ga pogađa, koji prekida logike njegova gledanja i življenja, koji ga izvlači iz njega samoga i mijenja ga u samome dnu njega samoga. O čuđenju se rijetko ili barem nedovoljno govori u teologiji. Ipak, ono što je pathos filozofa ${ }^{15}$, treba biti i sastavni dio egzistencije teologa. U svezi s time (ali ne samo time), čini se neizostavnim osvrnuti se na Uvod u evangeličku teologiju Karla Bartha.

Barth tvrdi da »na početku svakog teološkog spoznavanja, istraživanja i mišljenja — pa tako i svake teološke riječi — stoji jedna specifična vrsta čuđenja«, koja rađa želju za učenjem. Budući da za onoga koji se bavi teologijom, »ne može biti govora da bi on jednoga dana mogao završiti s učenjem i da bi mu neobično moglo postati uobičajenim, a ono novo dobro poznatim [...], [o]nog čuđenja koje tvori zdravi korijen teologije, čovjek se nikada ne može osloboditi $\ll .16$

U Sedmim odajama Zamka duše, kada govori o razlici između teorijskoga i iskustvenoga znanja, s obzirom na Presveto Trojstvo, Terezija ovako opisuje svoje iskustvo: »svakog se dana duša sve više zadivljuje « $(\mathrm{Z} 7,1,7)$. Čuđenje/divljenje ne stoji samo na početku iskustva, nego ono raste što su iskustvo i spoznaja veći. Radi se o gestama otvorenosti pred stvarnošću/događajem. To je prevažno za teologiju; o toj postavci sve ovisi. Na tragu Bartha, može se reći da ako teolog nema takav stav pred predmetom svoje znanosti, »to bi značilo da još nije niti ušao u teologiju ili pak da je već iz nje izišao «. ${ }^{17}$

Kod Terezije, divljenje ima važnu ulogu unutar spoznajnoga procesa. Onkraj subjektivizma i sentimentalizma, divljenje potiče i izaziva razum, dovodi ga do krajnjih granica:

»O beskrajne darežljivosti, kako su veličanstvena Vaša djela. Onoga kome razum nije zaokupljen ovozemaljskim stvarima, zaprepašćuje što ga nema da shvati istine. A na to što dušama koje su Vas toliko uvrijedile udjeljujete tako neograničene milosti, meni doista staje razum, pa kad dođem do toga da mislim na to, ne mogu krenuti dalje. Kamo mora ići a da to ne bude vratiti se natrag? Da Vam

14 E. Salmann, Presenza di spirito. Il cristianesimo come gesto e pensiero, Padova, 2000, str. 194.

15 F. W. J. Schelling, Filosofia della rivelazione, Milano, 1997, str. 899. Izričaj da je čuđenje/divljenje pathos filozofa, pripisuje se Platonu.

16 K. Barth, Uvod u evangeličku teologiju, Zagreb, 2007, str. 43-44.

17 Isto, str. 44. 
zahvali na tako velikim milostima, ne zna kako bi« $(\check{Z} 18,3)^{18}$. Terezija također govori o divljenju nad sobom samom: »vidim tajne u nama samima, koje me često puta preneraze (me traen spantada), a koliko ih tek mora biti! [...] jer su u nama samima velike tajne koje ne dokučujemo« $(\mathrm{Z} 4,2,5)$.

\section{- Intellectus — refleksija kao rast u ljubavi}

Taj se događaj ne iscrpljuje u početnome trenutku, ma koliko on bio snažan. ${ }^{19}$ Kod Terezije refleksija je najintimnije povezana s iskustvom. Iskustvo je tjera na refleksiju, na interpretaciju, na zauzimanje stava. Refleksija, dakle, nije samo interpretacija događaja, nego i globalna (re-)interpretacija, definiranje samoga sebe, novi početak (vida nueva).

Refleksija produbljuje iskustvo. Bez nje, nema iskustva u pravome smislu riječi. »Da bi postalo iskustvo u pravom smislu, [...] treba mu se dati smještaj i značenje, treba biti reflektirano ${ }^{20}$

Da za Tereziju refleksija pripada iskustvu, jasno je iz toga što ne samo početni događaj — doživjeti, biti obuzeta — nego i moći razumjeti pripisuje Bogu, izvoru i horizontu temeljne pogođenosti: »da me Gospodin nije poučio, ja bih s knjigama mogla malo naučiti, zato što ne bijaše ništa ono što sam shvaćala sve dok mi Njegovo Veličanstvo putem iskustva nije davalo da shvatim « $(Z ̌ Z 22,3) .{ }^{21}$ Mistično iskustvo rezultira potrebom i sposobnošću definirati i razumjeti samu sebe kao stvarnost pogođenu i rasvijetljenu od strane izvora događanja. ${ }^{22}$ Intelekt nije neovisan; postaje primatelj svjetla, ulivenoga dara koji nadilazi svakodnevna iskustva. ${ }^{23}$ Proces mišljenja ujedno je i proces ostvarenja same sebe.

Za Tereziju - i to je ključno - teološka refleksija ne doprinosi samo spoznaji, nego i ljubavi prema Bogu. Dapače, bez nje nema ljubavi, »jer ako ne spoznamo što primamo, ne potičemo se na ljubav« $(\check{Z}$ 10, 4). Ili na drugome mjestu:

18 »Zaista bi ovdje valjalo, kada bi se moglo razgovarati s nekim tko bi poznavao filozofiju, zato što bih se, poznavajući svojstva stvari, mogla izraziti, jer uživam u tome i ne mogu to iskazati« (Put 19, 3). »Bog prisiljava razum da pazi, makar mu bilo teško, da shvati ono što se kaže, jer čini se da tamo duša ima druge uši kojima čuje, te je prisiljava da sluša i da se ne rastresa, poput nekoga tko bi dobio um i ne bi mu se dopustilo da začepi uši, te bi mu se ujedno govorilo glasno, pa makar i ne bi htio, čuo bi to, i, najzad, nešto čini, budući da pazi kako shvatiti ono što mu se govori. Tu pak ništa, jer joj se oduzima čak i ovo malo što se sastoji samo u slušanju, što je činila ranije « (Ž 27, 8).

19 E. Salmann, Presenza di spirito. Il cristianesimo come gesto e pensiero, Padova, 2000, str.194.

20 Isto, str. 85.

21 I još: »Ono što hoće da duša shvati, Gospodin ulijeva u najdublju nutrinu duše i [...] čini da duša shvati ono što on hoće, i velike istine i tajne « (Ž 27, 6).

22 E. Salmann, Presenza di spirito. Il cristianesimo come gesto e pensiero, Padova, 2000, str. 198

23 »Nije to sjaj koji bi zasljepljivao, nego jedna blaga bjelina i uliven sjaj što pruža preveliku nasladu vidu i ne zamara, a niti zasljepljuje svjetlost što se vidi da bi se vidjela ova tako božanska ljepota. Ta je svjetlost toliko različita od ovih ovdašnjih, da se sunčeva svjetlost koju gledamo čini tako potamnjela u usporedbi s onim svjetlom i svjetlošću [...]. To je svjetlost koja ne poznaje noći, nego je, budući da je uvijek svjetlost, ništa ne muti. Najzad, takva je da, koliko god velika uma bila neka osoba, u sve dane svojega života ne bi mogla zamisliti kakva je. A Bog je upali tako brzo, da čak ne bi bilo ni prilike da se otvore oči, kad bi ih trebalo otvoriti. No nije ni bitno da li su otvorene ili zatvorene. Kad Gospodin hoće, vidimo čak i ako nećemo. Nema rastresenosti koja bi bila dostatna, niti ima moći da se odupre« $(\check{Z} 28,5)$. 
»ljubili bismo Ga znatno drugačije nego što Ga ljubimo, kada bismo Ga poznavali« (PS 30, 5). To i jest konačni smisao svake teološke spoznaje! Drugim riječima, razumijevanje koje je svojstveno teologiji treba biti način uspostave intimnijega odnosa s Bogom, rast u ljubavi prema njemu. Upravo se zato stvarno može govoriti o teološkoj vjerničkoj egzistenciji, odnosno o biti-teolog kao poslanju i načinu definiranja sebe samoga pred Bogom.

\section{- Confessio - teologija odjenuta mistagogijom i doksologijom}

Tek izreći iskustvo znači živjeti ga u punini. Jezik nije puko formuliranje nakon dogođenoga iskustva. Jezik organizira i prožima iskustvo ${ }^{24}$, te stvara nove mogućnosti iskustva. ${ }^{25}$ On je mjesto življenja iskustva: »stoga mi se čini — piše Terezija — da je vrlo velika prednost biti kod toga (biti u molitvi koju opisuje, op.a.) dok ovo pišem« $(\check{Z} 14,8)$.

Terezija opisuje svoja iskustva prvenstveno kako bi veličala Boga: »O Bože moj, kad bi čovjek imao razbora, znanja i novih riječi da uzveliča Vaša djela kako to moja duša shvaća $(\check{Z} 25,17)$ - radi se, dakle, o doksologiji ${ }^{26}$ — i kako bi druge oduševila za Boga: »Njegovo Veličanstvo zna da je, uz posluh, moja namjera kod duša pobuditi želju za tako uzvišenim dobrom « (Ž 18, 8), što pokazuje snažan mistagoški element »njezine teologije «.

Odjenuta formom doksologije i mistagogije ${ }^{27}$, Terezijina su djela svjedočanstvo Božjega zahvata u njezin život, njezin istinski confessio fidei. Kao i »druga milost « — razumjeti — tako i »znati izreći«, za Tereziju je posebna milost, događaj novoga, intenzivnijega odnosa s Bogom. Zato i riječi kojima opisuje iskustvo doživljava darovanima: »jasno vidim da nisam ja ta koja to kaže, jer niti to slažem s razumom niti kasnije znam kako sam to uspjela reći« $\left(\check{Z}\right.$ 14, 8). ${ }^{28}$ Izricanje neizrecivoga ne pripada njoj, makar se izriče upravo preko njezinih riječi. Tu se dolazi do važne točke vezane uz Terezijin confessio fidei: ako se objava povjerava jeziku/riječi, dakle, u slučaju Terezije confessio, onda se confessio ne odnosi samo

24 G. O'Collins, Teologia fondamentale, Brescia, 1988, str. 62.

25 E. Salmann, Presenza di spirito. Il cristianesimo come gesto e pensiero, Padova, 2000, str. 88.

26 Von Balthasar je u pravu kada kaže da se teologija ne može zadovoljiti time da služi samo boljem razumijevanju božanskih stvari (ad maiorem gnosim rerum divinarum), niti samo usavršavanju čovjeka ili napretka ljudskoga društva (ad maiorem hominis perfectionem et progressum generis humani), nego temeljno mora biti na veću slavu Božje ljubavi (ad maiorem divini amoris gloriam). H. Urs von Balthasar, Samo je ljubav vjerodostojna, Zagreb, 1999, str. 6. Mislimo da nije pretjerano reći da je potrebno teologijom slaviti Boga.

27 Doksološki i mistagoški element kod Terezije se često isprepliću. To je jasno posebno ako se ima na umu da ona ne piše sustavno. Primjeri su bezbrojni. Donosim samo neke koji mi se čine najznačajnijima: »dobro zna moj Gospodin da ne težim ničemu drugom u tome (u iznošenju svojih iskustava, op.a.), osim da malko bude hvaljen i veličan « ( $\check{Z}$ 10, 7.9); »reći ću neke stvari na njegovu slavu. Neka dade Njegovo Veličanstvo da koristi kakvoj duši [...] i da se potaknu na služenje Njegovom Veličanstvu svi« (Ž 37, 1).

28 »Kada Gospodin daje duha, iznosi se s lakoćom i bolje. Čini se kao da čovjek ima pred sobom predložak po kojem izvodi vez. Ali ako nedostaje duha, nije moguće uskladiti ovaj govor — kao i govoriti arapštinom, da se tako izrazim — makar se niz godina provede u molitvi« $(\check{Z} 14,8)$. 
na fides qua, nego i na fides quae. Ispovijest vjere, svjedočanstvo, nije samo čin vjere nego i čuvar objave. ${ }^{29}$

Fundamentalna teologija, kao ona instanca teologije koja se bavi pitanjem čina vjere, mora otkrivati mistagoški i doksološki smisao kršćanske egzistencije, ali mora otkriti i kako teologiju integrirati u doksologiju i mistagogiju. To svakako ne znači »usmjeravanje « teologije isključivo na liturgiju ili kršćansku inicijaciju, nego zaodjenutost misli i riječi o otajstvu onom formom koju je kršćanstvo od početka držalo potpuno prikladnom za njegovo posredovanje.

\section{Sadržaj iskustava: Bog kao djelujuće središte ljudske egzistencije}

Prelazimo na sadržaj Terezijinih iskustava. Do sada se moglo vidjeti kako se sadržaj Terezijinih djela rađa iz iskustva kojih dinamizam očituje pravu teološku metodu. U tome se vjera očituje kao stvarnost u nastajanju, »hodočašće mišljenja, koje još ostaje na putu «. ${ }^{30}$ Sadržaj koji se daje nije hermetički zatvoreni polog. Terezija je uvjerena da se samo iz iskustva u kojem se daruje »živi i pravi Bog « (I 56) može biti dostatno sposoban i odvažan za obrazlaganje vjere. Doista, »o onome o čemu se nema iskustva, teško se može sigurno obrazlagati« $(\mathrm{Z} 6,9,4){ }^{31}$

\subsection{Molitva: dogadaj objave $i$ čin vjere}

Najprije treba poći od činjenice da Terezija u svojim djelima opisuje milosti koje mi je Gospodin udijelio u molitvi (̌̌ 10, 8). Molitva je ambijent Terezijina nauka. Terezija je ne samo naučiteljica molitve — naslov koji joj je dao Pavao VI. — u smislu da podučava o molitvi, nego je molitva mjesto iskustava, ambijent njezine teologije. ${ }^{32}$ Molitvi je povjeren sav objavljeni sadržaj u svojoj najvećoj objektivnosti $^{33}$, ali ona je također najsubjektivniji čin kojim Terezija živi objav-

29 Sveto pismo, koje se često definira kao Božja riječ izrečena ljudskom riječi, primarni je dokaz da se objava povjerava ljudskom jeziku. Dakle, jezik ima sposobnost dohvatiti objavu i staviti je u (svoje) forme. Ljudski jezik prikladan je da se objava priopći i razumije. Usp. R. Fisichella, Oportet philosophari in theologia III, u: Gregorianum 76 (1995), str.718-720.

30 J. Ratzinger, Vjera i teologija, u: Isti, Zajedništvo u Crkvi, Split, 2008, str. 18.

31 U prijevodu Terezijinih djela na hrvatski jezik navedena rečenica glasi: »o onome o čemu se nema iskustva, teško se može dati siguran dokaz«. Španjolski izvornik glasi: «De lo que no hay experiencia, mal se puede dar razón cierta «. Dar razón je ključni glagol programatskog teksta fundamentalne teologije iz $1 \mathrm{Pt} 3,15$, koji govori o obrazlaganju nade (i vjere). Naime, na španjolskom jeziku, »obrazlagati nadu « kaže se »dar razón de la esperanza « (usp. cjeloviti naslov fundamentalne teologije Pié-Ninot-a: La teología fundamental. »Dar razón de la espernaza« (1 Pe 3, 15), Salamanca 2001). Stoga dar razón prevodimo s obrazlagati, čime ono i na hrvatskom, kao u izvornom španjolskom, i na semantičkom polju ima dodirnu točku s programatskim tekstom fundamentalne teologije.

32 Stoga i ne čudi što u njezinim djelima naracija spontano prelazi s govora o Bogu na govor Bogu, molitvu njemu upravljenu, zatim Božji govor njoj, pa njezinu komunikacija s čitateljem, često kao poziv na molitvu.

33 »Uvijek čujemo kako je molitva dobra, a i prema Konstitucijama moramo je imati toliko sati, no ne razjašnjuje nam se više od onoga što same možemo, a o Gospodnjim učincima u duši malo se kaže $\lll(\mathrm{Z} 1,2,7)$. 
ljene sadržaje. ${ }^{34}$ Molitva je za Tereziju par excellence događaj prožetosti između fides quae i fides qua.

Za nju, »molitva nije ništa drugo doli razgovarati prijateljski često puta nasamo s Onim za kojega znamo da nas ljubi« $(\check{Z} 8,5)$.

Konstitucija Dei Verbum, po mnogima najznačajniji dokument Koncila ${ }^{35}$ jer daje odgovor na pitanje u kakvoga Boga Crkva vjeruje, kako se taj Bog komunicira čovjeku, i koje su implikacije te komunikacije, kaže da Bog koji je ljubav »u bujici svoje ljubavi zapodijeva razgovor s ljudima kao prijateljima«. Ovdje se nalazi bitna poveznica s naukom svete Terezije. Koliko nam je poznato, ideja Boga kao prijatelja tipično je (judeo)kršćanska. Nijedna druga religija (ni filozofija) ne poznaje Boga koji bi htio biti prijatelj čovjeku. Ta će ideja pratiti njezino iskustvo Boga, i u trojstvenoj ${ }^{36}$ i kristološkoj dimenziji. ${ }^{37}$

Molitva, koja za Tereziju znači biti iste naravi kao Bog — »jer da bi ljubav bila istinska i da bi trajalo prijateljstvo, trebaju se složiti naravi« $(Z \text { Z } 8,5)^{38}$ — nije događaj poništenja ljudskoga. Baš ona čini da se pred Bogom bude različit i otkrije samoga sebe $\mathrm{u}$ istini: »ako ćete razgovarati onako, kako dolikuje razgovarati s tako velikim Gospodinom, dobro je da pogledate s kime razgovarate $i$ tko ste vi (PS 22,1). Dakle, molitva je događaj najveće blizine, istosti $\mathrm{s}$ Bogom ${ }^{39}$, ali istodobno i najveći događaj različitosti, drugosti. Molitva konstituira čovjeka u njegovoj vlastitoj realnosti: samo ondje gdje je Bog Bog, ja mogu biti ja. ${ }^{40}$ Stoga nekoherentnost molitve i života Terezija opisuje kao »jedan od najmučnijih života što mi se čini da se može zamisliti [...]. To je tako mučan rat« $(\check{Z} 8,2)$.

34 Začuđujuće je kako u rječniku Fundamentalne Teologije (R. Latourelle - R. Fisichella (ur.), Dizionario di Teologia Fondamentale, Assisi 1990.) nema termina molitva. To nije slučaj s velikim pothvatima kao što su Lexikon für Theologie und Kirche i Sacramentum Mundi: K. Rahner, Gebet (Dogmatisch), u: J. Höfer — K. Rahner (ur.), Lexikon für Theologie und Kirche IV2, 542-545), J. Sudbrack, Preghiera, u: K. Rahner (ur.), Enciclopedia Teologica. Sacramentum Mundi 6, Brescia, 1976, str. 469-487; navodimo talijansko izdanje koje nam je pri ruci.

35 Pié-Ninot, primjerice, taj dokument naziva »magna charta fundamentalne teologije «. S. Pié-Ninot, La teologia fondamentale, Brescia, 2002, str. 29.

36 »[Duša se] u jednom času osjeti tako mudrom i s tako jasnom spoznajom o tajni Presvetog Trojstva, i o drugim vrlo uzvišenim stvarima, da nema teologa s kojim se ne bi usudila raspravljati o istini ovih veličajnosti. Duša ostane tako začuđena da je dostatna jedna od ovih milosti da je izmijeni cijelu i navede je da ne ljubi ništa doli Onoga koji je, bez ikakva njezina truda, čini sposobnom za tako velika dobra, te joj priopćuje tajne i postupa s njom tako prijateljski i s toliko ljubavi da se to ne da opisati« (̌̌ 27, 9).

37 »U prisutnosti tako dobrog prijatelja, uz tako dobrog zapovjednika koji je stao na čelo u trpljenju, sve se može podnijeti. Pomoć je i daje hrabrost; nikad ne zakazuje; istinski je prijatelj « $(Z \mathbf{Z} 22,6)$.

38 »Ah, kako dobar prijatelj postajete, Gospodaru moj! Kako li ga tetošite i trpite te čekate da se prikloni Vašoj naravi i kako brzo podnosite njegovu!«

39 Molitva je per connaturalitem put sjedinjenja čovjeka i Boga. Terezija je zove »realni put« — camino real (PS - prva redakcija — 35, 2), sigurni put. Ona odgovara strukturi čovjeka.

40 Zato će reći da je molitva ulaz u Zamak duše, dakle, put samospoznaje. 


\subsection{Bog povijesti spasenja}

Terezijin Bog najprije je Bog povijesti spasenja, uključen u život čovjeka. Već naslov prvoga poglavlja knjige Moj život, »u kojem govori kako ju je Gospodin počeo poticati«, daje nagovijestiti da Bog nije samo objekt, nego nadasve subjekt ljudske egzistencije.

Iako nema stranice u kojoj ne opisuje Boga povijesti spasenja, izdvojit će se jedan tekst iz Života. U njemu se, uz već spomenuti Terezijin stav čuđenja pred otajstvom, spontano iznjedruju Božji atributi, njezina slika Boga koju nipošto nije mogla naučiti iz priručnika/duhovnih knjiga svoga vremena:

»Puno puta sam zaprepaštena mislila o velikoj Božjoj dobroti i naslađivala se moja duša videći njegovu veliku darežljivost i milosrđe. [...]. Koliko god nevaljala i nesavršena bila moja djela, ovaj moj Gospodin ih je popravljao, usavršavao i davao im vrijednost, a zla i grijehe zatim skrivao. [...]. Pozlaćuje krivice, čini da zasja krepost koju sam Gospodin unosi u mene, gotovo me prisiljavajući da je posjedujem « $(\check{Z} 4,10)$.

Bog koji »pozlaćuje krivice«, »skriva zla i grijehe«, uistinu je Bog koji se ne boji zaprljati čovjekom. On je za nju najprije objekt relacije, zajedništva, štoviše prisnosti: »ovaj moj Gospodin «. On koji je neizmjerno drukčiji, veći... da bi ostao drugi, nema potrebu držati nas u beskrajnoj distanci od sebe samoga ${ }^{41}$. Dapače, najveći dokazi njegove neizmjernosti njegova je snishodljivost: »Ah, Gospodine moj! Ah, Kralju moj! Tko li bi mogao sada iskazati veličajnost koju posjedujete! Nemoguće je ne vidjeti da ste sami u sebi veliki Vladar, te se zadivi tko gleda tu veličajnost. Još se više čudi, Gospodine moj, tko gleda Vašu poniznost i ljubav koju iskazujete nekome kao što sam ja« $(\check{Z} 37,6)$.

Ovo su razlozi zbog kojih će teologija za Tereziju uvijek biti nezaobilazna i za razumijevanje kršćanske egzistencije. Iz iskustva kršćanskoga življenja rađa se teologija u obliku sinteze: zadnje odaje Zamka duše strukturalno daju sintezu Terezijina iskustva, o čemu će se dalje izlagati samo u osnovnim crtama.

\subsubsection{Otajstvo Presvetoga Trojstva}

U Terezijinim djelima nalazi se mnoštvo trinitarnih tekstova. U njima se snažno očituju i Božja jedincatost i različitost osoba Presvetoga Trojstva. Ovdje se može navesti tek pokoji ulomak. »O dušo moja, promisli veliku nasladu i veliku ljubav, što je osjeća Otac poznajući svoga Sina, i Sin spoznajući svoga Oca i žar, s kojim se Duh Sveti sjedinjuje s njima. Promisli da se nijedna osoba ne može odvojiti od te ljubavi i spoznaje, jer su sve tri jedno isto biće. Ove se vrhovne Osobe poznaju, ljube se i uzajamno se naslađuju« (VDB 7, 2).

Za Tereziju nema sumnje da »Bog, onakav kakav je u svojoj vlastitoj neovisnoj suverenosti i slavi, može biti sadržaj i središte ljudske egzistencije i da to

41 Usp. K. Rahner, Hrabrost biti crkveni kršćanin, u: Isti, Teološki spisi. Izbor, M. Matić (ur.), Zagreb, 2008, str. 504. 
u slobodnoj milosti stvarno hoće biti«42: »Pa čemu treba moja ljubav? Zašto je išteš, Bože moj, što li s njom dobivaš? O blagoslovljen budi Ti!« (VDB 7, 2). Pristup »imanentnom Trojstvu « ostvaruje se po »ekonomijskom Trojstvu« koje je slobodno i nepatvoreno Božje sebepriopćenje — »Božja veličina nema granice, a isto tako je neće imati ni Njegova djela « $(Z 7,1,1)$ — pri čemu je važna otvorenost čovjeka bez koje se objava ne može ostvariti. Ta otvorenost nije samo čovjekov temeljni stav, nego može ići do te razine da se čovjek »puni [...] onim božanstvom te na neki način uživa [...] u sebi posjedujući sve tri osobe« (I 18). Naravno, inicijativa je uvijek Božja i on »daje kada hoće, kako hoće i komu hoće, kao vlastita dobra, a da ne čini krivo nikome « $(\mathrm{Z} 4,1,2)$.

S epistemološke točke gledišta, Terezijina trinitarna iskustva potvrđuju da je Bog objekt spoznaje posebno ondje gdje je objekt ljubavi, tako da je »onaj tko ljubi Boga potaknut, na određen način, postati teolog« (Benedikt XVI. $)^{43}$.

\subsubsection{Otajstvo Krista}

Božja uključenost u čovjekov život tolika je da je sam postao čovjekom. To je najveće prijateljstvo. Uvjet zajedništva je utjelovljenje. Terezija nudi jednu predivnu definiciju utjelovljenja koja može produbiti ideju prijateljstva sadržanu u konstituciji Dei Verbum. Naziva ga »veliko združenje u kojem je Bog postao čovjekom; ono prijateljstvo što ga je sklopio s ljudskim rodom « (MLJB 1, 10).

Kristovu čovještvu posvećuje dva velika poglavlja: 22. Moga života i 7. poglavlje šestih odaja Zamka duše.

Iz Terezijina opisa Kristova čovještva izdvaja se sljedeće: Krist je u svome čovještvu posrednik i punina objave ${ }^{44}$; sva otajstva — ne samo Pashalni misterij — Isusova života spasenjski su događaji (Ž 13, 13; PS 26) ${ }^{45}$; Krist je causa exemplaris $^{46}$, causa efficiens $^{47}$ i causa finalis ${ }^{48}$ čitava kršćanskog življenja; te nešto što

42 K. Rahner, Teološka dimenzija pitanja o čovjeku, u: Isti, Teološki spisi. Izbor, M. Matić (ur.), Zagreb, 2008, str. 383.

43 http://w2.vatican.va/content/benedict-xvi/it/speeches/2010/december/documents/hf_ben-xvi_ spe_20101203_cti.html

44 »Jasno vidim, a i kasnije sam uvidjela, da bismo ugodili Bogu i da nam udjeljuje milosti, kako hoće da to bude iz ruku ovoga presvetog Čovještva [...]. Jasno sam uvidjela da kroz ta vrata moramo ući ako hoćemo da nam nenadmašivo Veličanstvo razotkrije velike tajne.

Prema tome neka Vaša milost, gospodine, ne zaželi drugoga puta, makar se nalazila na vrhuncu motrenja. Po njemu idete sigurno. Ovaj naš Gospodin jest taj po kojem nam dolaze sva dobra. On će to pokazati« (̌̌ 22, 6-7).

45 Time se Terezija dotiče vrlo važne kristološke teme, poznate pod nazivom teologija otajstva Isusova života. Posljednjih godina ponovno se sve više otkriva njezina važnost unutar sustavne teologije. Jedan takav pokušaj nalazi se u izvrsnoj studiji J. G. García, Teología de los misterios de la vida de Jesús, Salamanca, 2009.

46 »Promotrimo li njegov život, najbolji je uzor« (̌̌ 22, 6-7). Također Z 5, 3, 7.

47 »On će nam pružiti svoju ruku da bismo se uzdigli iznad svojih mogućnosti« $(\check{Z}$ 22, 10).

48 Mnoštvo je tekstova koji o tome svjedoče. Izdvajamo samo jedan u kojem u sakramentu euharistije vidi već da ostvarenje konačnog zajedništva s Bogom u Kristu: »nema toga tko bi mogao posumnjati da je sam Gospodin, posebice odmah nakon pričesti, kad već znamo da je tu, jer nam to kaže vjera. Prikazuje se takvim Gospodarom one nastambe, te se čini da duša sva poništena iščezava u Kristu« $(\check{Z}$ 28, 8). 
nam se čini jako važnim, posebno ako se vodi računa da je Terezija mističarka: trajno značenje Kristova čovještva za čovjekov odnos s Bogom (I 6, 3). ${ }^{49}$ Slijedom toga, Terezija u euharistiji vidi eminentan događaj Kristova posredništva: u njoj se Bog daruje čovjeku, ali ona je i događaj kojim se čovjek — uvijek u Kristu — izručuje Bogu (PS 35, 5).

Krist je »ljepota koja nadvisuje sve ljepote« $(\mathrm{Pj} 6)$, ali i »ljepota koja sadrži u sebi sve ljepote «(PS 22, 6), pa je stoga ljudska duša, dakle čovjek, »velika ljepota s kojom ništa nije usporedivo « $(\mathrm{Z} 1,1,1)$. Kršćanski je život »život skriven s Kristom u Bogu« $(Z$ 5, 4, 2). Ovim je nagoviještena tema kojom se nadalje bavimo.

\subsubsection{Otajstvo čovjeka u Kristu}

Upravo Božja dobrostivost, a ne njegova izoliranost, dovode Tereziju do važnih antropoloških zaključaka. Čovjek je »sposoban uživati Njegovo Veličanstvo, kao što je i kristal da na njemu bljeska sunce« $(Z 1,2,1)$, i »ne nalazim ništa s čime da usporedim veliku ljepotu jedne duše i onu veliku sposobnost « $(\mathrm{Z} 1,1,1) .{ }^{50}$ Stoga će Terezijino promišljanje o čovjeku uvijek biti svojevrsna teološka antropologija. Otajstvo čovjeka postaje jasno u otajstvu Krista, koje je kao »zrcalo u koje je urezana naša slika« $(Z 7,2,8) .51$

Kada kaže da »se duša [ne može] naslađivati ičim doli Bogom«, Terezija govori o čovjeku ne samo kao stvorenom od Boga, nego i biću čije je konačno os-

49 Usp. K. Rahner, Vječno značenje Isusova čovještva za čovjekov odnos prema Bogu, u: Isti, Teološki spisi. Izbor, M. Matić (ur.), Zagreb, 2008, str. 130-143. Rahner piše da je kršćanska mistika »uvijek bila u kušnji (sve do Ivana od Križa) da u mističnom činu traži iščeznuće svega pred Bogom, tako da su uvijek bile potrebne naknadne korekture jednog takvog panteističkog temeljnog polazišta, da bi se moglo ostati pri tome da se mistik smije i može baviti Kristovim čovještvom «. Isto, 138. Terezija nikada nije pala u »takvu kušnju«. Upravo takvu pseudomistiku ona naziva »obmanom«, a u 22 poglavlje Moga života opisuje »kako sredstvo za najuzvišeniju kontemplaciju mora biti Kristovo čovještvo« (iz naslova poglavlja).

50 Orig. španj. "gran hermosura « $\mathrm{i}$ »gran capacidad«. Razvidno je da je čovjek za Tereziju capax Dei. Ta je istina potvrđena na Drugome vatikanskom koncilu u Konstituciji Gaudium et Spes: »Sveto pismo, naime, uči da je čovjek stvoren 'na sliku Božju', sposoban da spozna i ljubi svoga Stvoritelja« (GS 12). Nije ni čudno što je Henri de Lubac Gaudium et Spes držao tekstom koji nudi osnovne crte kršćanske antropologije. Makar to nije njezina prva ni ključna postavka — ona je posebno značajna u kontekstu otvorenosti Crkve prema svijetu (kulturi) — očito je da se radi o antropološki bogatome tekstu (posebno I. poglavlje u kojem se govori o strukturi čovjeka, pitanju grijeha i smrti, slobode i savjesti, itd.). Usp. F. G. Brambilla, Antropologia teologica, Brescia, 2009, str. 25. I Katekizam Katoličke Crkve, čiji je cilj »vjerno i organski izložiti nauk [na] način kako bi odgovorio pitanjima našega doba « (Ivan Pavao II) uvodi u sveukupnost katoličkog nauka govorom o čovjekovoj otvorenosti za Boga - homo capax Dei. Taj je pristup posebno blizak fundamentalnoj teologiji. Vidi: S. Pié-Ninot, La teologia fondamentale. »Rendere ragione della speranza $(1$ Pt 3, 15), Brescia, 2002, str. 73-212.

51 »Dok sam jedanput molila Časoslov sa svima, moja se duša odjednom sabra i učini mi se da je sva kao jasno zrcalo. Ni otraga ni sa strane, ni odozgo ni odozdo nije bilo ništa što ne bi bilo posve jasno, a u središtu mi se ukaza Krist, naš Gospodin, onako kako ga običavam vidjeti. Činilo mi se da ga u svim dijelovima svoje duše vidim jasno kao u zrcalu. A i to se zrcalo - ne znam iskazati kako — sve usijecalo u samoga Gospodina združivanjem prepunim ljubavi« (Ž 40,5). Donosimo i notu izdavača vezanu uz ovaj tekst: »Od svih milosti što ih svetica iznosi u Životu, ova je doktrinarno jedna od najbogatijih. Iz nje je niknula knjiga Zamak duše (usp. Odaje I, pogl. 1) i jedno od najljepših poglavlja Puta (pogl. 28, br. 9-12; usp. k tome i Izvj. 24, 16 i 18)«. 
tvarenje samo u zajedništvu s Bogom (usp. GS 19). Zato su i njezini tekstovi poprilično eshatološki prožeti: »umirem od želje da vidim Boga, a nisam znala gdje bih tražila taj život osim u smrti. Obuzimale su me tako velike gorljivosti ove ljubavi, da nisam znala što bih činila sa sobom« (Ž 29, 8). Vjerojatno jedan od najljepših redaka koji izražava Terezijinu eshatološku napetost je vivo sin vivir en mi, y tan alta vida espero, que mиеro porque no тиеro ( $\mathrm{Pj} 1)$. »Terezijina eshatologija sjedinjuje promišljanje o povijesti kao mjestu meta-povijesnog, ali i čežnju za meta-povijesnim, kao konačnim ispunjenjem povijesti.

\subsubsection{Otajstvo Crkve i za kršćansku vjeru}

Refleksija o onome što se događalo u njezinoj duši za Tereziju nikada nije bila puka introspekcija. Prvenstveno ju je zanimalo je li sve što joj se događa i u što vjeruje »u skladu s onim čega se drži sveta Katolička rimska Crkva « (Z Uvod, 3). Iako inzistira na osobnome iskustvu Božjega djelovanja, bez kojeg se ne mogu istinski razumjeti ni Božja riječ niti bilo što vezano uz kršćanski nauk, ona je daleko od svake vrste subjektivizma. Crkva je jamac objektivnoga, a osobna vjera za Tereziju i nije ništa drugo doli učiniti svojim ono što Crkva naučava i živi. U njezinim djelima više se puta pojavljuje fraza »lo que tiene la Iglesia« — »ono čega se drži Crkva«, a uvijek s obzirom na iskustvo vjere koje traži objektivnu sigurnost. ${ }^{52}$ Odnosno, kod Terezije je neupitna nužnost Crkve za puno življenje i mišljenje kršćanskoga otajstva, a time i za ozbiljenje vjere. Sloboda time nije ugrožena, nego se daje voditi na putu posredovanja objektivne istine: »čvrsto vjerovati u ono što je od Svete Majke Crkve, pa je posve sigurno da idete po dobrom putu «(PS 21, 10).

Vjera primljena i življena u zajednici, uvijek je i preuzimanje odgovornosti za druge, za zajednicu, za zajedničko dobro ${ }^{53}$. Doista, »stvar nije u tome da se puno razmišlja nego da se puno ljubi« $(\mathrm{Z} 4,1,7)$. Terezijino življenje otajstva završava u praksi, u služenju. Ljubav prema Kristu i strast za duše kod Terezije nisu alternative. »Ta najveća je služba, što ti je mogu učiniti, da ostave Tebe radi ljubavi i koristi njihove (ljudske) djece ${ }^{54}$. Onda će te istom potpunije posjedovati« (VDB 2, 2).

Boga se, kaže Terezija, u ljubavi prema bližnjemu »potpunije posjeduje«. Ta ideja čini nam se poprilično originalnom. Ljubav prema drugome nije samo najsigurniji znak, la más cierta señal, ljubavi prema Bogu, nego je njezino svojevrsno

$52 » S$ tom ljubavlju prema vjeri, što je Bog ulijeva, a koja je čvrsta, živa vjera, neka uvijek nastoji postupati u skladu $s$ onim čega se pridržava Crkva, raspitujući se kod jednih i drugih, poput nekoga tko je već čvrsto prionuo uz ove istine, te je ne bi skrenule svekolike objave što bi ih mogla zamisliti — sve da i otvorena nebesa vidi — ni za trunak od onoga čega se pridržava Crkva« ( $\check{Z}$ $25,12)$.

53 To je kod Terezije toliko izraženo da je ne samo »odlučila učiniti ono malo što je bilo do mene« (PS 1,2), dakle, svoj doprinos za rast Crkve, nego joj je ponekad »izgledalo kako su se sva zla i krivovjerja bila pojavila zbog mojih grijeha « $(\check{Z} 30,8)$, dakle, odgovornost za zajednicu-tijelo kojega je dio.

54 Kao primjer navodi Samarijanku, koja »ostavlja samog Gospodina da dobiju i okoriste se i ljudi iz njezina grada $($ MLJB 7, 6). 
ispunjenje, dovršenje ljubavi prema Bogu. To nam postaje još jasnije kada se iz mnoštva tema vezanih uz ekleziologiju svete Terezije, za kraj izdvoji kategorijapripadnosti Božjem narodu. Zadnje su Terezijine riječi ove: »Blagoslovljen budi Bog, što sam kći Crkve«. Pripadati Crkvi nije samo početak, nego i ispunjenje kršćanske egzistencije.

\section{Teološki rad i molitva}

Terezija Avilska, uz to što je naučiteljica molitve, poznata je (možda čak i poznatija) kao osnivateljica mnogih klauzurnih samostana. To je razlog zbog kojeg je njen život bio dinamičan ne samo u duhovnom, nego i fizičkom smislu. Bila je energična i u kontemplaciji i u akciji. Zanima nas, u najkraćim crtama, odnos molitve i (teološkog) rada, ne samo jer se de facto teologija bavi tim pitanjem, nego i jer de iure teološki rad ne može biti odvojen od molitve..$^{55}$

Poznata je famozna Terezijina izreka: »Među loncima je Gospodin«(O 5, 8). Njome ne izriče samo Božju sveprisutnost, nego i važnost jedinstva između molitve i rada. Tako za Tereziju rad nije tek susljedni element molitve (koliko god bilo važno moliti prije rada, posebno prije teološkoga rada), nego svojim radom čovjek uspostavlja odnos s Bogom. Rad se, lišen prizvuka aktivizma, pretvara u događaj dijaloga čovjeka i Boga. Djelovanje odnosno rad je, dakle, izričaj samoga sebe pred Bogom. Ono nije samo činjenje radi Boga, donošenje djela pred Boga, nego i donošenje sebe pred Boga. Može se zaključiti da kršćanin mora imati neku vrstu identifikacije s onim što radi, makar se njegova egzistencija ne može reducirati na djelovanje. Kod Terezije je jasan prioritet: molitva je na prvome mjestu. Rad ne može zamijeniti molitvu, ali — rad može postati molitva. Ovakav pristup radu pomaže i samom shvaćanju molitve: ona nije tek »poći na tankanje « (von Balthasarov prigovor) ${ }^{56}$, nego čin ljubavi bez koje rad nikada neće postati dijalog s Bogom.

»Teologija na koljenima« ne sastoji se samo u tome da teolog uz to što piše i moli, pa niti u tome da moli prije negoli će nešto pisati, stvarati, nego i po tome što se čitava egzistencija teologa, a time i njegov teološki rad, odvija u poniznosti, u prigibanju pred Onim »u kom je sve blago mudrosti i znanja« (usp. Kol 2, 3).

\section{Zaključak}

Terezija Avilska nije bila teologinja u akademskom smislu riječi. Nije podučavala teologiju. Također, interes za Tereziju više se pokazao sa strane duhovnosti, povijesti, pa i književnosti, nego sa strane sustavne teologije. Već je napomenuto

55 »Prije svega, i na poseban način prije teologije, nužno je započeti molitvom, [...] kako bismo se stavili u njegove ruke i sjedinili s njime«. Dionysius Areopagita, De Divinis Nominibus, III 1, 680 d. Tekst navodim prema talijanskom izdanju: Dionigi Areopagita, Tutte le opere, G. Reale (ur.), prev. P. Scazzoso, Milano, 2009.

56 H. Urs von Balthasar, Samo je ljubav vjerodostojna, Zagreb, 1999, str. 74. 
da se Terezija ne dotiče svega čime se bavi fundamentalna teologija, niti je ovim želimo prisvojiti za fundamentalnu teologiju. Ipak, njezina djela mogu ne samo biti promatrana fundamentalno-teološki, nego se u njima nalaze oni elementi koji mogu biti poticaj(n)i ovoj teološkoj grani.

$\mathrm{U}$ tome je dijalog Terezije i fundamentalne teologije: njezina djela promatrana fundamentalno-teološki, dakle, iščitavanje njezinih iskustava kao govora o Bogu izraslog iz Božjega govora u konkretnoj ljudskoj povijesti, otkriva vrijednost koju ta djela nose - kao eminentno teološka literatura. S druge strane, Terezija izaziva fundamentalnu teologiju na izlazak iz akademske zatvorenosti, ne samo u smislu konfrontirajućega dijaloga, nego i u smislu da svojom refleksijom iznalazi odnos s Bogom. To je put kojim vjera i ljubav tvore neodvojivu cjelinu.

Povezanost metode i sadržaja, što je u samoj srži Terezijine teologije, čuva fundamentalnu teologiju od opasnosti ad extra redukcionizma. Prije nego granič$n a$, fundamentalna je temeljna, odnosno ona ima pravo biti granična samo ako je temeljna teologija iskustva kršćanske vjere, bez da se pri tom ograničava na pojedinačna iskustva.

Ako teologija ne želi samo biti scientia, nego sapientia - u korijenu čega je sapor — onda je jasno da se mora okrenuti iskustvu, i — više - mora postati iskustvo, u trostrukoj dimenziji koja se pronalazi kod Terezije. Naime, pokazalo se da se kod Terezije sadržaj njezinih djela rađa iz dinamizma affectus-intellectus-confessio, pri čemu svaki »korak« u metodi doprinosi većoj spoznaji i ljubavi, odnosno za Tereziju metoda u teologiji nužno uspostavlja intimniji, bliskiji odnos s objavljenom istinom.

Samo tako razrađena teologija u stanju je nadići intelektualizam i biti kadra egzistencijalno obrazložiti razloge nade i vjere, postati fundamentalna u pravom smislu riječi. 
Saint Teresa's Rightful Place in Fundamental Theology

Edvard Punda*

Summary

In this the year 2015 we celebrate the 500th anniversary of the birth of St. Teresa of Avila (1515-1582). Seeing as she was the first woman upon whom the title of Doctor of the Church was conferred, her sanctity therewith affirmed, and the eminent teachings contained in her works substantiated, even theology itself is in a way impelled to direct its attention toward her. Therefore this great jubilee is an excellent opportunity to present this saint from Avila herewith to the Croatian theological community in which Teresa is just barely present. It is our intention to present the theological relevance of Teresa's thought in such a way that a place may be alloted to Teresa herself in the world of theology, to be specific, in fundamental theology. The first section explains the importance of experience as the cognitive-affective process which generated Teresa's works. Within this process is concealed a true theological method which the author proposes to fundamental theology since it is the theological discipline which is held most accountable for determining method in theology. The second section proffers a systematic cross-section of theological content that was lived out and thought out in the course of mystical experience. We are speaking here of the happy union between fides quae creditur and fides qua creditur whereby revealed truths are centermost to the Christian existence without being reduced to individual experience. Finally, with reference to Teresa's thought, we point out the importance of prayer for our theological reflection, but also the fact that work in the field of theology can become prayer.

Key words: Teresa of Avila, fundamental theology, experience, theological method, prayer

* Edvard Punda, Th. D., The Catholic Faculty of Theology, The University of Split. Adress: Zrinsko-frankopanska 19, 21000 Split, Croatia. E-mail: donedvard@gmail.com 